\title{
Effect of polyaluminum chloride on enhanced softening for the typical organic-polluted high hardness North-China surface waters
}

\author{
Mingquan Yan ${ }^{\mathrm{a}, \mathrm{b}}$, Dongsheng Wang ${ }^{\mathrm{b}, *}$, Jinren $\mathrm{Ni}^{\mathrm{a}}$, Jiuhui Qu ${ }^{\mathrm{b}}$, You Yan ${ }^{\mathrm{c}}$, Christopher W.K. Chow ${ }^{\mathrm{d}}$ \\ a Department of Environmental Engineering, College of Environmental Sciences, Peking University, Beijing, 100781, China \\ b State Key Laboratory of Environmental Aquatic Chemistry, Research Center for Eco-Environmental Sciences, Chinese Academy of Sciences, POB 2871, Beijing 100085, China \\ c Waterborne Transportation Institute, Beijing 100088, China \\ ${ }^{\mathrm{d}}$ CRC for Water Quality and Treatment, Australian Water Quality Centre, SA Water Private Mail Bag 3, Salisbury, South Australia 5108, Australia
}

\section{A R T I C L E I N F O}

\section{Article history:}

Received 1 December 2007

Received in revised form 14 February 2008

Accepted 14 February 2008

\section{Keywords:}

Enhanced softening

Magnesium

Natural organic matter

$\mathrm{pH}$

Polyaluminum chloride

\begin{abstract}
A B S T R A C T
The treatment of organic-polluted high hardness surface water by enhanced softening via precipitation using various coagulants, such as $\mathrm{FeCl}_{3}, \mathrm{AlCl}_{3}$ and polyaluminum chloride ( $\mathrm{PACl}$ ), was investigated in bench scale experiments. Higher removal of natural organic matter (NOM) $\left(\mathrm{UV}_{254}\right.$ removal reaches about 50\%) is achieved by enhanced softening with coagulant addition conditions as compared with conventional coagulation at natural $\mathrm{pH}$ or by softening alone without coagulation. It is found that $\mathrm{PACl}$ could enhance the formation of $\mathrm{Mg}(\mathrm{OH})_{2}$ precipitate to remove NOM efficiently at relative lower $\mathrm{pH}$ range $(\mathrm{pH}<10)$. Under this circumstance, the $\mathrm{pH}$ for enhanced softening can be decreased significantly into the practical $\mathrm{pH}$ range for treatment plant operation. The efficiency of enhanced softening is affected significantly not only by $\mathrm{pH}$, coagulant type and dose, but also by raw water quality such as NOM characteristics, magnesium content and hardness. NOM with more hydrophobic content and higher molecular weight may be removed more easily in some situations. For water with higher content of $\mathrm{Mg}^{2+}$, the inflexion $\mathrm{pH}$ for favorable $\mathrm{UV}_{254}$ removal is lower. It is of practical value for organic-polluted water with high content of magnesium to be treated by enhanced softening with PACl.
\end{abstract}

(c) 2008 Elsevier B.V. All rights reserved.

\section{Introduction}

Natural organic matter (NOM) in source water can cause odor, taste, color, and bacterial regrowth problems during distribution for drinking water supply. More importantly, NOM is the precursor for health concerning disinfection by-products (DBPs), such as trihalomethanes (THMs) and haloacetic acids (HAAs). The US Environmental Protection Agency (USEPA) has proposed more stringent maximum contaminant levels (MCLs) of 80 and $60 \mu \mathrm{g} / \mathrm{L}$ for THMs and HAAs, respectively in finished drinking water [1,2]. Removal of NOM in an effective way is one of the major challenges in modern drinking water industry. Enhanced softening, improving the removal of DBPs precursor by precipitative softening, was recommended by the USEPA as one of the best available technologies to control the formation of DBPs [1].

Softening is employed in drinking water treatment primarily for the removal of polyvalent metallic ions, principally calcium and magnesium. Previous research indicates that only limited NOM removal can be achieved during the conventional softening pro-

\footnotetext{
* Corresponding author. Tel.: +86 10 62849138; fax: +86 1062923541.

E-mail addresses: Yankingcn@yahoo.com (M. Yan), wgds@rcees.ac.cn (D. Wang).
}

cess [3-6]. Even the use of high doses of lime (200 mg/L) may not be effective to remove DBP precursors due to electrostatic repulsion arising from the high negative charge density of humic substances and the negatively-charged calcium carbonate dense crystalline surface [7-9]. Altering the surface character of calcium carbonate precipitates by adding cationic polyelectrolytes is an alternative option to enhanced NOM removal during softening [10,11].

Unlike calcium carbonate, magnesium hydroxide precipitates as positively-charged particles with an amorphous structure and larger surface area $[3,6]$. It is found that a small increase in magnesium precipitation results in a significant NOM removal [12]. Systems that remove at least $10 \mathrm{mg} / \mathrm{L} \mathrm{Mg}$ hardness as $\mathrm{CaCO}_{3}$ are proposed to exempt from the enhanced softening requirements by the USEPA [1]. However, for typical concentrations of magnesium in raw water supplies, the precipitation of magnesium hydroxide requires high $\mathrm{pH}$ (above 11) condition, which is uncommon in water treatment practice [13]. It is not an attractive choice for softening plants. Addition of coagulant (e.g. activated silica, ferric chloride and organic polymers) during softening was proposed as alternative to enhanced NOM and particle removal [14].

Polyaluminum chloride ( $\mathrm{PACl}$ ) has been claimed by many investigators to be superior to the traditional coagulants for high alkalinity and $\mathrm{pH}$ water due to the fact that the prehydroylzed 
polymer in $\mathrm{PACl}$ is positively charged and relatively stable at high $\mathrm{pH}$ range [15-17]. However, the influence of PACl on enhanced softening is still unclear. This paper investigates the performance of PACls on enhanced softening compared with traditional coagulants such as $\mathrm{AlCl}_{3}$ and $\mathrm{FeCl}_{3}$. The typical source waters from North-China were selected as examples because they are not only polluted seriously by recalcitrant synthetic organic contaminants [18], but also are of high alkalinity, $\mathrm{pH}$ and hardness.

\section{Materials and methods}

\subsection{Materials}

Four coagulants, $\mathrm{AlCl}_{3}, \mathrm{FeCl}_{3}, \mathrm{PACl}_{1}$, and $\mathrm{PACl}_{22}$, were used in this study. $\mathrm{AlCl}_{3}$ and $\mathrm{FeCl}_{3}$ were of reagent grade. $\mathrm{PACl}_{\mathrm{I}}$, commercial $\mathrm{PACl}$ product, was provided by a local factory (Beijing Wanshui Water Cleaning Agent CO., China), which was produced by dissolving $\mathrm{Al}(\mathrm{OH})_{3}$ solids. $\mathrm{PACl}_{22}$ (Basicity of $2.2, \mathrm{OH} / \mathrm{Al}$ molar ratio, simplified as $B$ values), was prepared by the base titration method in laboratory at room temperature [19]. The $\mathrm{Al}$ species distribution in the PACls and $\mathrm{AlCl}_{3}$ samples was analyzed by Ferron (Sigma, UK) assay [15]. The chemical species of hydrolyzed $\mathrm{Al}(\mathrm{III})$ can be divided through the different reaction rates into three types: monomeric species $\left(\mathrm{Al}_{\mathrm{a}}\right)$ (instantaneous reacted), medium polymer species $\left(\mathrm{Al}_{\mathrm{b}}\right)$ (reacted less than $120 \mathrm{~min}$ ), and species of sol or gel $\left(\mathrm{Al}_{\mathrm{C}}\right)$ (no reaction within $120 \mathrm{~min}$ ). The results are shown in Table 1.

Three water samples with different water quality were taken from the typical North-China rivers. One was collected from the Yellow River in Autumn (YW); the others were collected from the Luan River during Summer $\left(\mathrm{LW}_{\text {Sum }}\right)$ and Winter $\left(\mathrm{LW}_{\mathrm{Win}}\right)$, respectively. The quality of the raw waters is presented in Table 2 .

\subsection{Jar testing}

Jar tests were performed on a programmable jar test apparatus (Daiyuan Jar Test instruments, China). The operation procedures were as follows: 1 L of raw water was transferred into a 1.4-L square beaker with sampling port $3 \mathrm{~cm}$ below water surface; the jar tester was started at rapid mixing of $300 \mathrm{rpm}$; after 30 s coagulant was added followed by mixing speed of $250 \mathrm{rpm}$ for $2 \mathrm{~min}$; $40 \mathrm{rpm}$ for $10 \mathrm{~min}$; and then after $20 \mathrm{~min}$ of quiescent settling, samples were taken for water quality measurement. In the enhanced softening experiment, predetermined amount of $\mathrm{NaOH}$ were dosed $15 \mathrm{~s}$ before adding coagulant during rapid mixing period. Coagulants as well as acid and base reagents were dosed using pipettes, which were calibrated before each experiment.

\subsection{Analysis}

Dissolved organic carbon (DOC) was analyzed by a TOC Analyzer (Phoenix 8000 system, Tekmar-Dohrman Co., USA) using the method of sodium peroxydisulphate/orthophosphoric acid wet oxidation and UV radiation after filtered through $0.45 \mu \mathrm{m}$ membrane. $\mathrm{UV}_{254}$ was measured by a spectrophotometer (UV-vis 8500 , China) at a wavelength of $254 \mathrm{~nm}$ using a $1 \mathrm{~cm}$ quartz cell after filtered through a $0.45 \mu \mathrm{m}$ membrane. Turbidity was measured using a
Table 1

The speciation distribution of coagulant-PACls by Ferron method

\begin{tabular}{lllcc}
\hline & $\mathrm{Al}_{\text {Total }}(\mathrm{mol} / \mathrm{L})$ & $\mathrm{Al}_{\mathrm{a}}(\%)$ & $\mathrm{Al}_{\mathrm{b}}(\%)$ & $\mathrm{Al}_{\mathrm{c}}(\%)$ \\
\hline $\mathrm{AlCl}_{3}$ & 0.200 & 91.9 & 8.1 & 0 \\
$\mathrm{PACl}_{\mathrm{I}}$ & 0.207 & 40.0 & 38.5 & 21.5 \\
$\mathrm{PACl}_{22}$ & 0.101 & 17.8 & 61.5 & 20.7 \\
\hline
\end{tabular}

2100N Turbidimeter (Hach, USA). pH was measured by a pHS-3C (Shanghai, China) $\mathrm{pH}$ meter, which was daily calibrated using $\mathrm{pH}$ 7.01 and $\mathrm{pH} 9.18$ buffers. The hardness, alkalinity and chemical oxygen demand $\left(\mathrm{COD}_{\mathrm{Mn}}\right)$ were measured by standard methods [20]. Metal elements ( $\mathrm{Ca}, \mathrm{Mg}$ and $\mathrm{Al}$ ) were analyzed by ICP-OES after filtered through a $0.45 \mu \mathrm{m}$ membrane (Agilent, USA). Dissolved organic matter (DOM) was characterized using resin absorbent and ultrafiltration (UF) fractionation methods described in the literature [18].

\section{Results and discussion}

\subsection{Comparison of coagulant type on enhanced softening}

Four typical coagulants, two metal salts, $\mathrm{FeCl}_{3}$ and $\mathrm{AlCl}_{3}$, and two PACls, $\mathrm{PACl}_{\mathrm{I}}$ and $\mathrm{PACl}_{22}$, were selected to examine the effect of coagulant type on softening. $\mathrm{NaOH}$ was used as softening reagent instead of the traditional softening agents lime and soda ( $\mathrm{CaO}$ and $\mathrm{Na}_{2} \mathrm{CO}_{3}$ ) to reduce the influence of $\mathrm{Ca}^{2+}$ addition on the softening process. The results of source water YW are shown in Fig. 1.

In Fig. 1a, all four coagulants follow a similar trend with residual turbidity increases against $\mathrm{pH}$ (adjusted by $\mathrm{NaOH}$ ) until the maximum is reached at approximately $\mathrm{pH} 10$. Further increase in $\mathrm{pH}$ (beyond 10) resulted in residual turbidities decrease. In order to evaluate the influence of coagulant on softening, samples were taken for water quality measurement only after 20 min of quiescent settling, in which $\mathrm{CaCO}_{3}$ and $\mathrm{Mg}(\mathrm{OH})_{2}$ precipitates were still in the form of suspended solid and at that point of time the residual turbidities for all four coagulants were relatively high (based on predetermined test).

As shown in Fig. 1b, low $\mathrm{UV}_{254}$ removal is observed at $\mathrm{pH}$ below 9.5 and it is even lower than at natural $\mathrm{pH}$ (the lowest $\mathrm{pH}$ point in the figures), especially for the two metal salt coagulants. The higher the $\mathrm{B}$ values of the $\mathrm{PACl}$, the better the $\mathrm{UV}_{254}$ removal at $\mathrm{pH}$ below 9.5. $\mathrm{UV}_{254}$ removal by $\mathrm{FeCl}_{3}$ is more efficient than $\mathrm{AlCl}_{3}$ and is less efficient compared with the two PACls. When $\mathrm{pH}$ increased to above 10 , the $U V_{254}$ removal increases significantly for all four coagulants but the removal performance of each coagulant is reversed, better $\mathrm{UV}_{254}$ removal is observed for PACls with lower $\mathrm{B}$ value and both metal coagulants out performed the PACls with the removal efficient in the order of $\mathrm{PACl}_{22}<\mathrm{PACl}_{\mathrm{I}} \approx \mathrm{FeCl}_{3}<\mathrm{AlCl}_{3}$.

The relative efficiency of $\mathrm{COD}_{\mathrm{Mn}}$ removal by the four coagulants (Fig. 1c) shows the same trend as in the case of $U_{254}$ removal except that $\mathrm{COD}_{\mathrm{Mn}}$ removal decreased more obviously at $\mathrm{pH}$ about 9.5, and that the increase of $\mathrm{UV}_{254}$ removal is more significant than that of $\mathrm{COD}_{\mathrm{Mn}}$ removal when $\mathrm{pH}$ increases from about 9.25 to 10 . This phenomenon may be linked with the inefficiency of turbidity removal at $\mathrm{pH}$ about 10 .

Table 2

Water quality characteristics of water samples

\begin{tabular}{|c|c|c|c|c|c|c|c|c|c|}
\hline & $\mathrm{pH}$ & Alkalinity (mg/L) & Hardness (mg/L) & Turbidity (NTU) & $\mathrm{UV}_{254}$ & $\mathrm{COD}_{\mathrm{Mn}}(\mathrm{mg} / \mathrm{L})$ & $\mathrm{DOC}(\mathrm{mg} / \mathrm{L})$ & $\mathrm{Mg}(\mathrm{mg} / \mathrm{L})$ & $\mathrm{Ca}(\mathrm{mg} / \mathrm{L})$ \\
\hline YW & 8.67 & 160 & 345 & 11.5 & 0.133 & 6.0 & 5.4 & 45.5 & 98 \\
\hline $\mathrm{LW}_{\text {Sum }}$ & 8.21 & 116 & 180 & 8.02 & 0.056 & 4.1 & 4.2 & 30.0 & 70 \\
\hline $\mathrm{LW}_{\text {Win }}$ & 8.61 & 135 & 150 & 0.92 & 0.063 & 3.5 & 3.2 & 19.8 & 52 \\
\hline
\end{tabular}



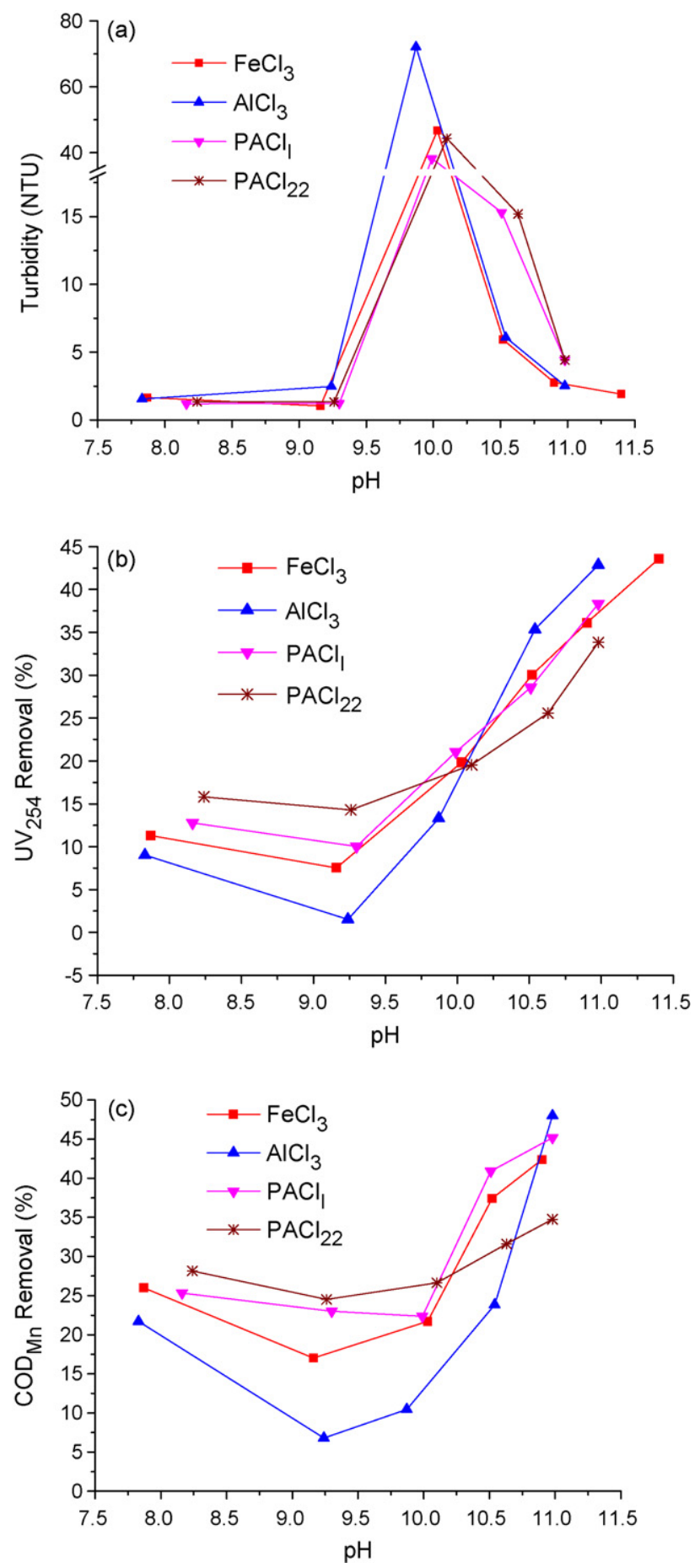

Fig. 1. The effect of coagulant type on enhanced softening with $\mathrm{NaOH}$ for the Yellow River water at dose of $0.08 \mathrm{mmol} / \mathrm{L} \mathrm{Al} / \mathrm{Fe}$. (a)Turbidity removal; (b) $\mathrm{UV}_{254}$ removal; (c) $\operatorname{COD}_{\mathrm{Mn}}$ removal.

\subsection{Effect of PACl on enhanced softening}

The performance of coagulants during softening may be seriously affected by coagulant hydrolyzing process, particularly the interaction of coagulant hydrolyzed speciation and the concentration of $\mathrm{Mg}^{2+}$ and $\mathrm{Ca}^{2+}$ ions. The performance of DOC, turbidity, $\mathrm{Ca}^{2+}$ and $\mathrm{Mg}^{2+}$ removal with or without $\mathrm{PACl}_{\mathrm{I}}$ under softening conditions by $\mathrm{pH}$ adjustment using $\mathrm{NaOH}$ was investigated with source water $\mathrm{LW}_{\text {Win. }}$. The results are shown in Fig. 2.
The residual turbidities increase with $\mathrm{pH}$ (the dose of $\mathrm{NaOH}$ ) and reach the maximum at about $\mathrm{pH} 10$ for both softening with $\mathrm{PACl}$ and softening alone (without $\mathrm{PACl}$ ) with 1 and $7 \mathrm{NTU}$, respectively. Once the $\mathrm{pH}$ increases beyond 10 , the residual turbidities decrease. The residual turbidities are significantly lower for softening with $\mathrm{PACl}$ than without $\mathrm{PACl}$ in the studied $\mathrm{pH}$ range. Just the softening process alone (without $\mathrm{PACl}$ ), only slight DOC removal is observed at $\mathrm{pH}$ below 10 . The use of $\mathrm{PACl}$ as coagulant under the softening conditions, higher DOC removal is observed as compared with softening alone. At $\mathrm{pH}$ above 10 , DOC removal is increased for both cases. The residual turbidity and DOC are affected by the residual $\mathrm{Ca}^{2+}$ and $\mathrm{Mg}^{2+}$ contents. The balance of $\mathrm{Ca}^{2+}$ and $\mathrm{CO}_{3}{ }^{2-}$, $\mathrm{HCO}_{3}{ }^{-}$is disturbed at $\mathrm{pH}$ about 9 , and large amount of $\mathrm{CaCO}_{3}$ precipitate is formed. During this process, the residual $\mathrm{Ca}^{2+}$ content decreases rapidly due to the precipitation of $\mathrm{CaCO}_{3}$ and at the same time the residual turbidity increased (Fig. 2c). When $\mathrm{pH}$ increased to $10, \mathrm{Mg}(\mathrm{OH})_{2}$ precipitate starts to form and the residual content of $\mathrm{Mg}^{2+}$ decreases (Fig. 2d). As a result of this process, the residual turbidity and DOC also decrease.

The removal of NOM, as well as other contaminants, by softening is largely controlled by the surface properties of calcium carbonate and magnesium hydroxide particles. Precipitation and coprecipitation are two possible mechanisms proposed for NOM removal during softening [21-23]. No matter which type of mechanisms is responsible for NOM removal, adsorption of NOM onto solid phase is essential. However, only limited amounts of NOM can be adsorbed onto the calcium carbonate surface due to electrostatic repulsion arising from the high negative charge density of humic substances and the negatively-charged calcium carbonate surface [7-9]. In addition, calcium carbonate is precipitated as a dense crystalline solid with very low surface area $\left(5 \mathrm{~m}^{2} / \mathrm{g}\right)$, as compared to other coagulants such as ferric chloride $\left(230 \mathrm{~m}^{2} / \mathrm{g}\right)$, which results in less available sites for NOM adsorption [6].

Unlike calcium carbonate, magnesium hydroxide precipitates as positively-charged, gelatinous precipitate with high surface area, which makes it an excellent adsorbent for negatively-charged humic substances. A significant amount of NOM can be removed by precipitation of magnesium hydroxide.

$\mathrm{PACl}$ plays a complicated role in the process of $\mathrm{NaOH}$ softening. $\mathrm{PACl}$ can promote magnesium precipitation, and the residual $\mathrm{Mg}$ is lower than that of the $\mathrm{NaOH}$ softening without $\mathrm{PACl}$ (Fig. 2d). At the same time, the pre-formed positively charged polymer in $\mathrm{PACl}$ is relative stable at high $\mathrm{pH}$ [15]. The $\mathrm{PACl}$ can act as a coagulant to remove particle and NOM at high $\mathrm{pH}$ in the softening process and also it can act as cationic organic polymer to reform the surface electrostatic properties of the products of $\mathrm{CaCO}_{3}$ precipitate [10]. In addition, the presence of $\mathrm{PACl}$ can reduce $\mathrm{CaCO}_{3}$ precipitation [24] and resulted in higher residual $\mathrm{Ca}^{2+}$ level as compared with $\mathrm{NaOH}$ softening without PACl (Fig. 2c). Then the residual turbidity is lower and the NOM could be removed more efficiently.

\subsection{Effect of coagulant dose and $\mathrm{pH}$}

The influence of coagulant dose and $\mathrm{pH}$ on the removal of turbidity and $\mathrm{UV}_{254}$ by $\mathrm{PACl}_{\mathrm{I}}$ for source water $\mathrm{YW}$ is shown in Figs. 3 and 4 , respectively. Coagulant dose and $\mathrm{pH}$ play significant roles in turbidity and $U_{254}$ removal. The condition of combining optimum dose and optimum $\mathrm{pH}$, higher $\mathrm{UV}_{254}$ and turbidity removal is achieved. The best $U_{254}$ removal is observed at a combination of high dose and high $\mathrm{pH}$ (Fig. 4).

\subsection{Comparison of enhanced softening with PACl for LW and YW}

The turbidity and NOM removal by enhanced softening with coagulant $\mathrm{PACl}_{\mathrm{I}}$ for three typical source waters were compared. The 

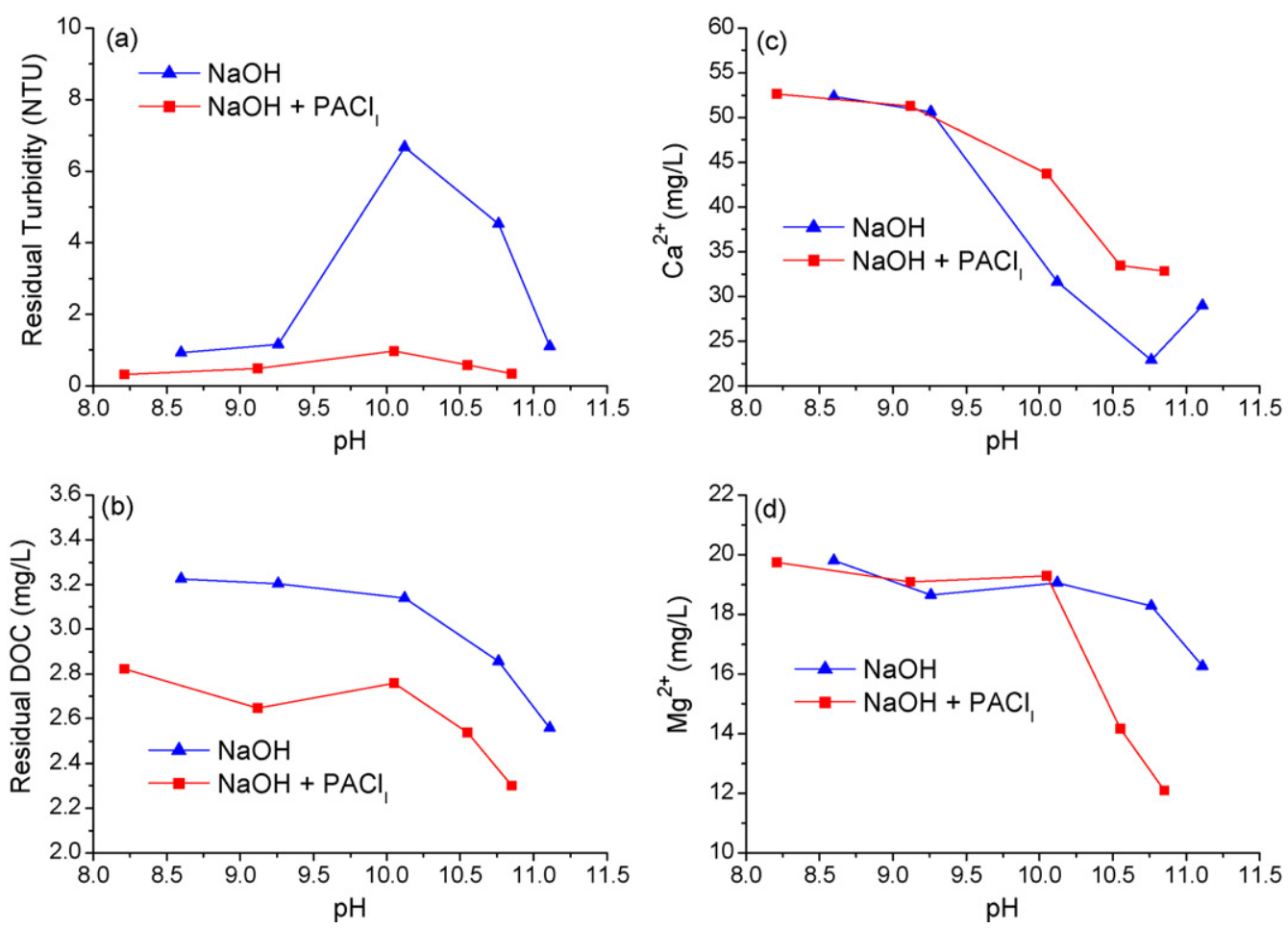

Fig. 2. The effect of $\mathrm{PACl}$ on softening by $\mathrm{NaOH}$ for the Luan River water in Winter.

results are shown in Fig. 5. It shows that the three source waters have the same enhanced softening behavior in general, such as the residual turbidity increases with the increase of $\mathrm{pH}$ (the dose of $\mathrm{NaOH}$ ), and it reaches the maximum at $\mathrm{pH}$ about 10 . When $\mathrm{pH}$ continuously increases, the residual turbidity drops. In the case of $\mathrm{UV}_{254}$ removal, it decreases slightly firstly at $\mathrm{pH}$ below 10 , then increases significantly when $\mathrm{pH}$ increases to above 10 .

It also shows some significant difference among the three waters due to the water characteristics. The first is that the inflexion $\mathrm{pH}$ for favorable $U_{254}$ removal is lower for the source water with higher content of $\mathrm{Mg}^{2+}$ (Table 2). The contents of $\mathrm{Mg}^{2+}$ are as high as 45.5, 30.0 and $19.8 \mathrm{mg} / \mathrm{L}$ for $\mathrm{YW}, \mathrm{LW}_{\text {Sum }}$ and $\mathrm{LW}_{\mathrm{Win}}$, respectively; and the

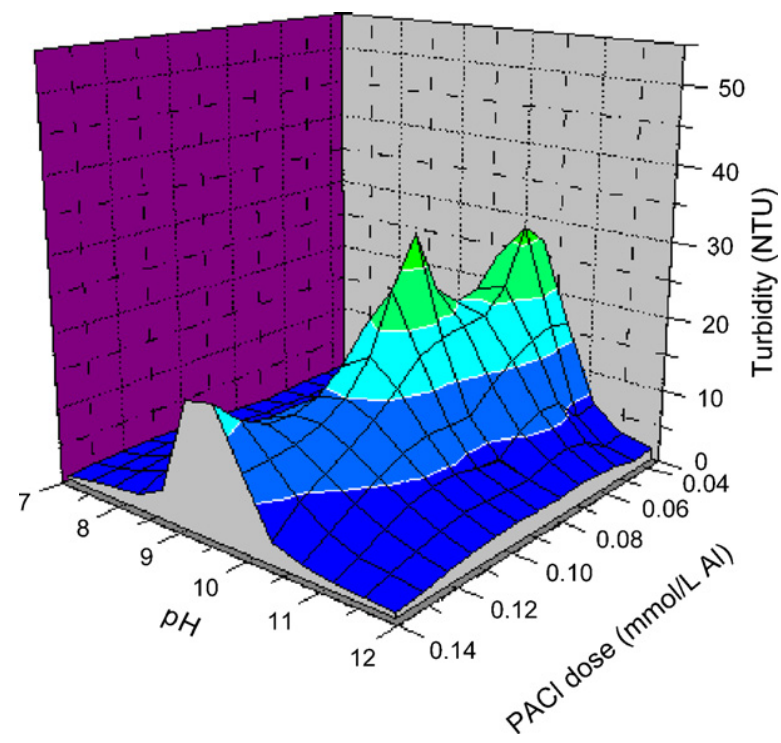

Fig. 3. The influence of coagulant dose and $\mathrm{pH}$ on turbidity removal by $\mathrm{PACl}$ for the Yellow River water. inflexion $\mathrm{pH}$ values for favorable $\mathrm{UV}_{254}$ removal are about 9.25, 9.75 and 10.0, correspondingly (Fig. 5b). Kvech and Edwards [24] have revealed that the presence of $\mathrm{Al}^{3+}$ can reduce significantly the solution of $\mathrm{Mg}^{2+}$ in synthetic water to about $27 \mathrm{mg} / \mathrm{L}$ from $\mathrm{pH} 9.25$ to 10 . The water with higher $\mathrm{Mg}^{2+}$ (above $27 \mathrm{mg} / \mathrm{L}$ ) content can produce more $\mathrm{Mg}(\mathrm{OH})_{2}$ precipitate to enhance NOM removal at a relatively lower $\mathrm{pH}$ range. The content of $\mathrm{Mg}^{2+}$ in source water $\mathrm{YW}$ is as high as $45.5 \mathrm{mg} / \mathrm{L}$, it is a suitable water source for enhanced softening treatment with $\mathrm{PACl}$ and the $\mathrm{UV}_{254}$ removal increases significantly at $\mathrm{pH}$ around 10 , which has great practical value in water plant operation.

The relative effectiveness of NOM removal shows significant difference among the three source waters. The $U_{254}$ removal for

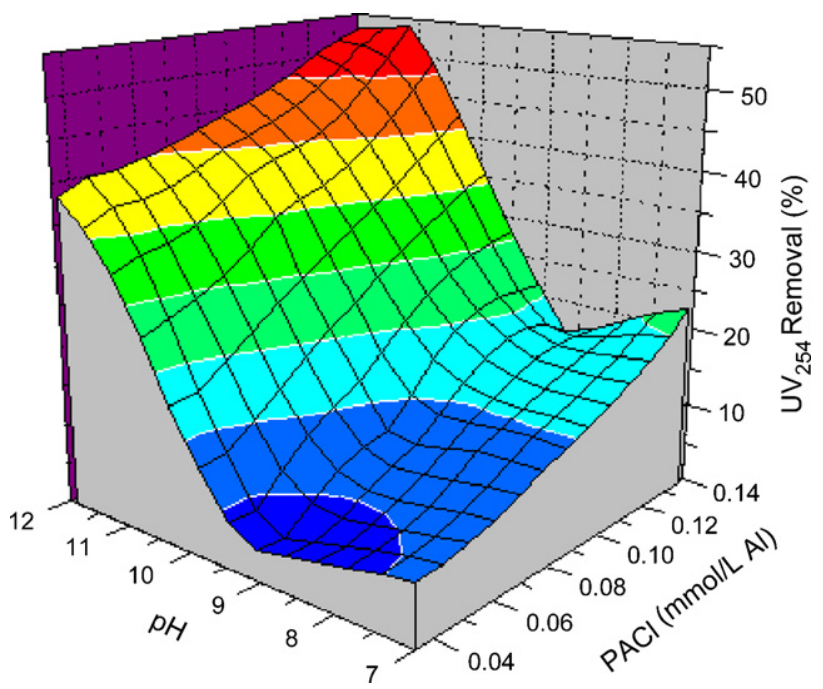

Fig. 4. The influence of coagulant dose and $\mathrm{pH}$ on $\mathrm{UV}_{254}$ removal by $\mathrm{PACl}$ for the Yellow River water. 

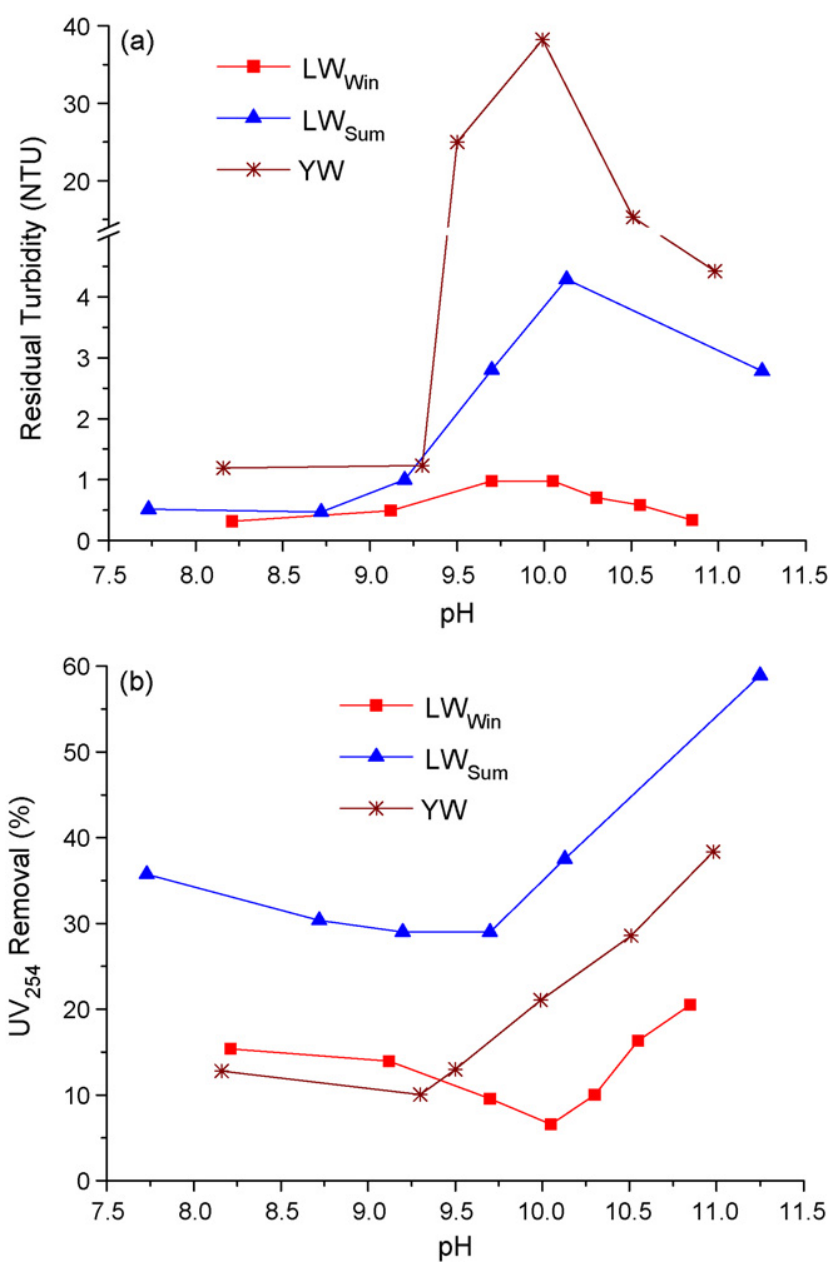

Fig. 5. The efficiency of enhanced softening with $\mathrm{PACl}$ for three source waters, the Yellow River water (YW), the Luan River water in Summer ( $\mathrm{LW}_{\text {Sum }}$ ), and the Luan River water in Winter $\left(\mathrm{LW}_{\text {Win }}\right)$. (a) Removal of $\mathrm{UV}_{254}$; (b) removal of turbidity.

$\mathrm{LW}_{\text {Sum }}$ is not only the most efficient by coagulation at natural $\mathrm{pH}$ (the lowest $\mathrm{pH}$ point in the figures), but also by softening with $\mathrm{PACl}$. Although $\mathrm{UV}_{254}$ removal for $\mathrm{YW}$ is as low as the $\mathrm{LW}_{\mathrm{Win}}$ by coagulation at natural $\mathrm{pH}$, it is more efficient than $\mathrm{LW}_{\text {Win }}$ by enhanced softening with $\mathrm{PACl}$ at high $\mathrm{pH}$. It could be due to the characteristics of organic contaminants.

The characteristics of DOM for the three source waters were determined by resin absorbent and UF fraction. The results are shown in Fig. 6. Although the percentage of hydrophobic DOC in YW is higher than $\mathrm{LW}_{\text {Sum }}$ and $\mathrm{LW}_{\text {Win }}$, it is only about $60 \%$ of the total DOC. It is lower than that in the well-protected source water, more than $70 \%[25,26]$. The $\mathrm{LW}_{\text {Sum }}$ and $\mathrm{LW}_{\text {Win }}$ are polluted seriously by low molecular weight DOM, especially the $\mathrm{LW}_{\text {Sum }}$ source accounting for about $65 \%$ overall DOM. It is unusually high compared with the commonly found value of no more than $40 \%$. Although DOM with molecular weight lower than $1 \mathrm{kDa}$ only accounts for $21 \%$ of the YW DOM, the fractions with molecular weight between 1 and $10 \mathrm{~K}$ is extremely high (65\%) [26,27]. Both rivers are highly polluted by recalcitrant synthetic organic matter, which is not easily removed by coagulation [25-27].

Although the percentage of hydrophobic and high molecular weight DOM in YW is higher than that in $\mathrm{LW}_{\text {Sum }}$, the DOM in YW may be harder to remove by enhanced coagulation with PACl [18]. It was found that the coagulable DOM in YW was more heterogeneous than $\mathrm{LW}_{\text {Sum }}$, and there was some DOM with high SUVA which
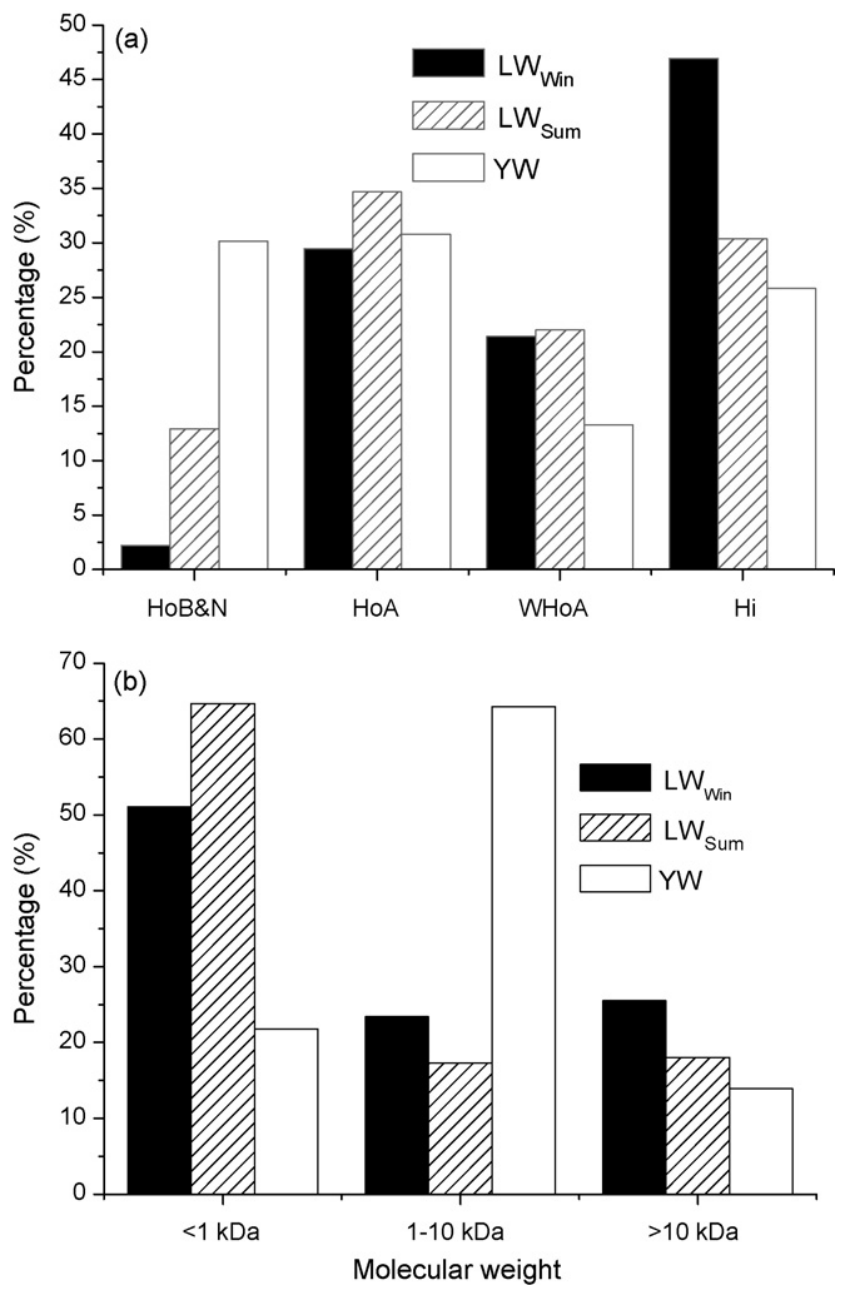

Fig. 6. Comparison of DOM fraction distribution by (a) resin absorbent and (b) ultrafiltration in the Yellow River water (YW), the Luan River water in Summer $\left(\mathrm{LW}_{\text {Sum }}\right)$, and the Luan River water in Winter $\left(\mathrm{LW}_{\mathrm{Win}}\right)$. Hydrophobic basic and neutral (HoB\&N), Hydrophobic acid (HoA), Weakly hydrophobic acid (WHOA), Hydrophilic (Hi).

could not be removed efficiently at moderate dose (generally high SUVA refers to the presence of easily removable DOM) [18]. While considering the two source waters from the Luan River, higher content of hydrophobic DOM in $\mathrm{LW}_{\text {Sum }}$ compared with $\mathrm{LW}_{\mathrm{Win}}$, the $\mathrm{UV}_{254}$ is removed more efficiently by coagulation at natural $\mathrm{pH}$ and coagulation under softening condition. Which is agreed with the results from Thompson et al. [12] that magnesium precipitation effectively remove the hydrophobic fraction of the organic carbon.

\section{Conclusion}

The effect of coagulants on enhanced softening (using $\mathrm{NaOH}$ ) for the typical North-China rivers is investigated in this paper and the main conclusions can be drawn as following.

(1) PACl can enhance $\mathrm{Mg}(\mathrm{OH})_{2}$ precipitate formation at relative low $\mathrm{pH}$ range $(\mathrm{pH}<10)$, and it is more efficient than $\mathrm{FeCl}_{3}$ and $\mathrm{AlCl}_{3}$ to improve the softening process for NOM and particle removal. Better NOM removal by enhanced softening with coagulant (achieved 50\% $\mathrm{UV}_{254}$ removal) compared with coagulation at natural $\mathrm{pH}$, and even greater improvement is observed as compared with softening without coagulant. It is also worth notice 
that the $\mathrm{pH}$ for enhanced softening could decrease significantly into the practical $\mathrm{pH}$ range for treatment plant operation.

(2) From the results, it is shown that the efficiency of enhanced softening is affected by coagulant type and dose, and water quality such as content of Mg, hardness and NOM characteristics. It is of practical value that for organic-polluted water with high content of $\mathrm{Mg}$, enhanced softening with $\mathrm{PACl}$ is a recommended treatment option.

(3) There are several aspects of enhanced softening require further investigation, such as developing coagulant with high $\mathrm{Mg}^{2+}$ content, developing positive electrostatic coagulant to enhanced $\mathrm{Mg}(\mathrm{OH})_{2}$ precipitation and surface modification of the surface charge of the $\mathrm{CaCO}_{3}$ precipitate.

\section{Acknowledgements}

The authors are very grateful for the kind help from the people who provided full supports to this research, specially for Dr. Quanshan Wei. The kind suggestions from the anonymous reviewers are greatly acknowledged. This research is funded by the NSF of China under 50578155, 50621804 and 20477054, the National Key Technology R\&D Program of China under 2006BAD01B03 and 2006BAD01B09, and national 863 projects under 2002AA126040. This project was supported by China Postdoctoral Science Foundation also.

\section{References}

[1] USEPA, Enhanced Coagulation and Enhanced Precipitative Softening Guidance Manual, EPA, Office of Water and Drinking Ground Water, Washington, DC, 1998, pp. 20-50.

[2] U. Iriarte-Velasco, J.I. Álvarez-Uriarte, J.R. González-Velasco, Enhanced coagulation under changing alkalinity-hardness conditions and its implications on trihalomethane precursors removal and relationship with UV absorbance, Sep. Purif. Technol. 55 (2007) 368-380.

[3] A.P. Black, R.F. Christman, Chemical characteristics of fulvic acids, J. Am. Water Works Assoc. 53 (1961) 897-916.

[4] S.J. Randtke, C.E. Thiel, M.Y. Liao, C.N. Yamaya, Removing soluble organic contaminants by lime-softening, J. Am. Water Works Assoc. 74 (4) (1982) 192-202.

[5] M.J. Semmens, A.B. Staples, The nature of organics removed during treatment of Mississippi River water, J. Am. Water Works Assoc. 78 (2) (1986) 76-91.
[6] S.J. Randtke, Organic contaminant removal by coagulation and related process combinations, J. Am. Water Works Assoc. 80 (5) (1988) 40-56.

[7] P. Somasundaran, G.E. Agar, The zero point of charge of calcite, J. Colloid Interface Sci. 24 (1967) 433-438.

[8] W. Stumm, Chemistry of Solid Water Interface, Wiley, New York, 1992.

[9] G. Newcombe, C. Donati, M. Drikas, R. Hayes, Adsorption onto activated. Carbon: electrostatic and non-electrostatic interactions, Water Supply 14 (1994) 129-144.

[10] M. Bob, H.W. Walker, Enhanced adsorption of natural organic matter on calcium carbonate particles through surface charge modification, Colloid Surf. A 191 (2001) 17-25.

[11] M. Bob, Enhanced Removal of Natural Organic Matter During Lime-Soda Softening. Dissertation for Ph.D, Ohio State University, Columbus, 2003.

[12] J.D. Thompson, M.C. White, G.W. Harrington, P.C. Singer, Enhanced softening: factors influencing DBP precursor removal, J. Am. Water Works Assoc. 89 (5) (1997) 64-79.

[13] J. Leentvaar, M. Rebhum, Effect of magnesium and calcium precipitation on coagulation-flocculation with lime, Water Res. 16 (1982) 655-662.

[14] E. Coro, S. Laha, Colour removal in groundwater through the enhanced softening process, Water Res. 35 (2001) 1851-1854.

[15] D.S. Wang, W. Sun, Y. Xu, H.X. Tang, J. Gregory, Speciation stability of inorganic polymer flocculant-PACl, Colloid Surf. A 243 (2004) 1-10.

[16] M.Q. Yan, D.S. Wang, J.H. Qu, W.J. He, C. Chow, Relative importance of hydrolyzed $\mathrm{Al}(\mathrm{III})$ species (Ala Alb and Alc) during coagulation with polyaluminum chloride: a case study with the typical micro-polluted source waters, J. Colliod Interface Sci. 316 (2007) 482-489.

[17] B.A. Dempsey, H. Sheu, T.T.M. Ahmed, J. Mentink, Poly-aluminum chloride and alum coagulation of clay-fulvic acid suspensions, J. Am. Water Work Assoc. 77 (3) (1985) 74-80.

[18] M.Q. Yan, D.S. Wang, S.J. You, J.H. Qu, H.X. Tang, Enhanced coagulation in a typical North-China water plant, Water Res. 40 (2006) 3621-3627.

[19] D.S. Wang, H.X. Tang, Modified inorganic polymer flocculant-PFSi: Its preparation, characterization and coagulation behavior, Water Res. 35 (2001) 3418-3428.

[20] APHA AWWA WEF, Standard Methods for the Examination of Water and Wastewater, 19th ed., American Public Health Association, Washington, DC, 1995, pp. 253-258.

[21] M.Y. Liao, S.J. Randtke, Removing fulvic acid by lime softening, J. Am. Water Works Assoc. 77 (8) (1985) 78-88.

[22] D.A.Skoog, D.M. West, Fundamentals of Analytical Chemistry, 2nd ed., Reinhart, New York, 1982.

[23] I.M. Kolthoff, The formation and properties of crystalline precipitates, J. Phys. Chem. 36 (1932) 860-881.

[24] S. Kvech, M. Edwards, Solubility controls on aluminum in drinking water at relatively low and high pH, Water Res. 36 (2002) 4356-4368.

[25] D.M. Owen, G.L. Amy, Z.K. Chowdhury, R. Paode, G. McCoy, K. Viscosil, NOM characterization and treatability, J. Am. Water Works Assoc. 87 (1)(1995)46-63.

[26] J.A. Leenheer, J.P. Croue, Characterizing aquatic dissolved organic matter, Environ. Sci. Technol. 37 (2003) 18A-26A.

[27] G.L. Amy, R.A. Sierka, J. Bedessem, D. Price, L. Tan, Molecular size distributions of dissolved organic matter, J. Am. Water Works Assoc. 84 (6) (1992) 67-75. 